\title{
PKM KELOMPOK TANI MILENIAL DI DESA CEPAKA, KEDIRI TABANAN
}

\author{
${ }^{1 *}$ Ni Kadek Yunita Sari, ${ }^{2}$ Anak Agung Ayu Putri Permatasari, ${ }^{3} \mathrm{Ni}$ Putu Widya \\ Astuti, ${ }^{4}$ Dylla Hanggaeni Dyah Puspaningrum
}

\author{
1,2,3,4 Fakultas IImu Kesehatan Sains dan Teknologi, Universitas Dhyana Pura, \\ Badung,Bali, Indonesia.
}

email: yunitasari@undhirabali.ac.id

\begin{abstract}
Abstrak
Salah satu perkebunan pandan wangi di Bali adalah kelompok tani milenial mengusung nama UD Melonila, yang terletak di Jalan Raya Munggu Kapal, Banjar Batanduren Desa Cepaka, Kediri, Tabanan, Bali. Sejauh ini pengembangan produk dari tanaman pandan wangi belum dilakukan. Inovasi pemanfaatan daun pandan wangi untuk membuat produk seperti simplisia masih belum dikembangkan. Sehingga Tim PKM berencana untuk melakukan pendampingan terhadap kelompok tani milenial di Desa Cepaka, Kediri, Tabanan untuk membuat produk simplisia. Permasalahan mitra:1) Mitra belum memiliki konsep dasar simplisia 2) Mitra belum memiliki keterampilan dalam membuat produk simplisia, 3) Mitra belum memiliki merk dagang dan kemasan produk hasil pengembangan produk. Solusi yang ditawarkan yaitu 1)Pelatihan melalui penyuluhan tentang konsep dasar simplisia meliputi definisi simplisia, kegunaan dan metode pengolahan daun pandan wangi menjadi simplisia, 2)Pelatihan dan pendampingan praktek membuat produk simplisia, 3)Pendampingan dan pelatihan membuat merk dagang dan desain kemasan. Hasil yang diperoleh dari PKM yaitu 1)Semua anggota mitra yang mengikuti sosialisasi mendapatkan rerata nilai pemahaman 84 pada post-test, 2)Mitra memiliki keterampilan dalam membuat produk simplisia, 3)Produk simplisia yang dihasilkan memiliki merek dagang dan kemasan penjualan.
\end{abstract}

Kata Kunci: Desa Cepaka, Kelompok Tani Milenial, Simplisia, Pandan Wangi

\begin{abstract}
One of the pandanus plantations in Bali is a millennial farmer group carrying the name UD Melonila, which is located on Jalan Raya Munggu Kapal, Banjar Batanduren, Cepaka Village, Kediri, Tabanan, Bali. So far, product development of the fragrant pandanus plant has not been carried out. Innovations in the use of fragrant pandanus leaves to make products such as simplicia have not yet been developed. So the PKM Team plans to provide assistance to millennial farmer groups in Cepaka Village, Kediri, Tabanan to make simplicia products. Partner problems: 1) The partner does not have the basic concept of simplicia 2) The partner does not have the skills in making simplicia products, 3) The partner does not have a trademark and product packaging resulting from product development. The solutions offered are 1) Training through counseling on the basic concepts of simplicia including the definition of simplicia, uses and methods of processing fragrant pandanus leaves into simplicia, 2) Training and practical assistance in making simplicia products, 3) Assistance and training in making trademarks and packaging designs. The results obtained from the PKM were 1) All partner members who took part in the socialization got an average understanding score of 84 on the post-test, 2) The partners had skills in making simplicia products, 3) The simplicia products produced had trademarks and sales packaging.
\end{abstract}

Keywords: Cepaka Village, Millennial Farmer Group, Simplisia, Pandanus fragrant 


\section{PENDAHULUAN}

Daun pandan merupakan salah satu tanaman yang mengeluarkan aroma yang wangi. Daun memiliki banyak manfaat khususnya dalam bidang pangan, dimana digunakan sebagai pewarna dan pengharum tambahan alami pada makanan. Namun daun pandan tidak hanya bermanfaat untuk makanan saja tetapi bisa dijadikan sebagai obat alternatif untuk mengobati berbagai penyakit .Kandungan kimia pandan wangi diantaranya alkaloid, saponin, flavonoid, polifenol, tannin, dan zat warna (Yadial, 2009). Menurut Dalimartha (2002), daun pandan wangi berkhasiat antioksidan, menghitamkan rambut, rambut rontok, lemah saraf, tidak nafsu makan, rematik, sakit perut disertai gelisah, serta pegal linu.

Salah satu perkebunan yang mengenbangkan tanaman pandan wangi di Bali adalah Melonila Bali, yang terletak di di Jalan Raya Munggu Kapal, Banjar Batanduren Desa Cepaka, Kediri, Tabanan, Bali. Usaha Dagang ini digagas oleh Arie Sutrisno dan diresmikan pada tanggal 17 Agustus 2019. Luas perkebunan Melonila sekitar 15 hektar terdiri dari 14 petak dan 60 bedengan. Perkebunan ini secara eksklusif menanam berbagai tanaman seperti tanaman pandan wangi, jahe, lengkuas, kunyit, kencur, sereh, singling, sirih dan singkong. Hasil perkebunan biasanya dipasarkan langsung di toko Melonila dan beberapa ada yang di bawa ke restoran, pasar tradisional, warung sembako dan warung lalapan.

Dibandingkan dengan tanaman lain yang ada di perkebunan Melonila, tanaman pandan merupakan produk yang memiliki daya beli yang paling sedikit. Sejauh ini tanaman pandan wangi sebagian besar dibeli oleh pedagang canang yang ada di kawasan tersebut. Berdasarkan permasalahan tersebut mitra ingin berinovasi mengembangkan produk dari tanaman pandan wangi.

Berdasarkan permasalahan

tersebut tim PKM berencana untuk melakukan pendampingan terhadap kelompok petani pandan wangi di Desa Cepaka, Kediri, Tabanan untuk membuat inovasi produk yaitu simplisia dari daun pandan wangi. Adapun permasalahan yang dihadapi mitra setelah dilakukan observasi di lapangan; 1) Mitra belum memiliki pengetahuan tentang simplisia dan metode pengolahan daun pandan wangi menjadi simplisia; 2)Mitra belum memiliki keterampilan dalam membuat produk simplisia; 3)Mitra belum memiliki merk dagang dan kemasan produk hasil pengembangan produk.

Permasalahan prioritas yang harus ditangani yaitu: 1) Meningkatkan pengetahuan tentang definisi simplisia, kegunaan dan metode pengolahan daun pandan wangi menjadi simplisia; 2) Meningkatkan keterampilan dengan memberikan pelatihan dan pendampingan mengenai pengembangan produk seperti pembuatan nama / brand produk, pembuatan desain kemasan produk; 3) Meningkatkan keterampilan melalui pelatihan dan pendampingan mengenai pengembangan dan pengemasan produk hingga strategi pemasaran.

\section{METODE PELAKSANAAN}

1. Konsep dasar simplisia

Kegiatan ini dilaksanakan dengan memberikan penyuluhan tentang pengertian simplisia, jenis-jenis simplisia dan teori teknik pembuatan simplisia pada mitra yaitu kelompok tani di Desa Cepaka Kediri Tabanan yang berjumlah 5 orang. Pemahaman konsep dasar simplisia diukur dengan memberikan pre-tes dan post-tes kepada mitra.

2. Keterampilan membuat simplisia

Kegiatan ini dilaksanakan dengan memberikan pendampingan praktek membuat simplisia daun pandan wangi pada mitra yaitu kelompok tani di Desa Cepaka Kediri Tabanan yang berjumlah 5 orang. Keterampilan membuat simplisia diukur dengan memberikan pre-tes sebelum pendampingan dan pos-tes setelah pendampingan dan dilihat dari keberhasilan produk yang dihasilkan.

3. Pengemasan produk dan menentukan merek dagang (brand)

Pengemasan produk dan penggunaan merek dagang sangat membantu dalam mengkomunikasikan serta mudah diingat oleh konsumen sehingga produk memiliki nilai jual dipasaran. Tim 
PKM mendampingi mitra yaitu kelompok tani di Desa Cepaka Kediri Tabanan dalam melakukan pengemasan, menentukan dan merancang desain logo yang sesuai untuk produk simplisia daun pandan wangi.

\section{HASIL DAN PEMBAHASAN}

Pengabdian masyarakat PKM Kelompok Tani Milenial di Desa Cepaka, Kediri Tabanan berlangsung mulai Bulan Agustus hingga bulan Desember 2020. Adapun hasil kegiatan yang dicapai antara lain:

\section{Konsep Dasar Simplisia}

Kegiatan penyuluhan tentang konsep dasar simplisia dilaksanakan dengan memberikan penyuluhan yang menyangkut tentang definisi simplisia, kegunaan dan metode pengolahan daun pandan wangi menjadi simplisia oleh narasumber. Pemahaman tingkat pengetahuan diukur dengan memberikan pre-tes dan pos-tes kepada mitra. Adapun hasil penyuluhan tentang simplisia dan metode pengolahan daun pandan wangi menjadi simplisia tertera pada Tabel 1. Berdasarkan hasil pada Tabel 1 terjadi peningkatan pengetahuan tentang definisi dan jenis simplisia dari hasil pre-test mitra 28 meningkat menjadi 85 pada post-test. Pada penyampaian materi kegunaan simplisia terjadi peningkatan pengetahuan dari 30 pada pres test menjadi 88 setelah post-test.

Penyampaian materi metode pembu atan simplisia meningkat dari rata-rata nilai 10 menjadi 80 setelah post-test. Berdasarkan rata-rata kegiatan keseluruhan didapatkan nilai 23 pada pre-test dan pengetahuan mitra meningkat menjadi 84 setelah post-test. Hasil tersebut menujukkan adanya pengaruh penyuluhan yang diberikan terhadap pengetahuan mitra, menurut Notoatmodjo (2012), pengetahuan seseorang dapat dipengaruhi oleh beberapa faktor,diantaranya: pendidikan, media dan informasi.

Tabel 1. Pengetahuan Tentang Simplisia dan Metode Pengolahan Daun Pandan Wangi Menjadi Simplisia Kegiatan

Rerata Pengetahuan mitra

\begin{tabular}{lcc} 
& Pre-test & Post-test \\
\hline Penyampaian materi definisi dan jenis simplisia & 28 & 85 \\
Penyampaian materi kegunaan simplisia & 30 & 88 \\
Penyampaian materi metode pembuatan simplisia & 10 & 80 \\
Rerata & 23 & 84 \\
\hline
\end{tabular}

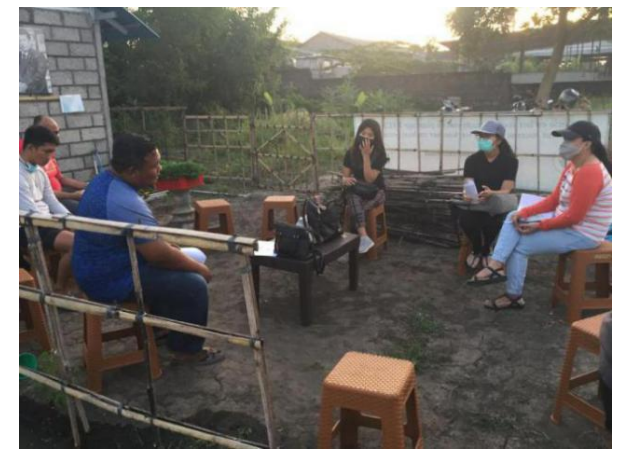

Gambar 1. Penyuluhan kepada Mitra

\section{Keterampilan Membuat Simplisia}

Kegiatan ini dilaksanakan dengan memberikan pelatihan dan pendampingan metode pembuatan simplisia. Keterampilan membuat simplisia diukur dengan memberikan pre-tes sebelum pendampingan dan pos-tes setelah pendampingan pembuatan produk. Adapun rata-rata hasil pretest dan postest yang diperoleh dari kelompok tani setelah mengikuti pelatihan dan pendampingan, sebagai berikut: 
Tabel 2. Rata-rata hasil pretest dan postest metode pembuatan produk simplisia

\begin{tabular}{cccc}
\hline $\begin{array}{c}\text { Jumlah } \\
\text { Peserta }\end{array}$ & Nama & $\begin{array}{c}\text { Rata-rata nilai } \\
\text { Pretest }\end{array}$ & $\begin{array}{c}\text { Rata-rata Nilai } \\
\text { Postest }\end{array}$ \\
\hline 5 orang & $\begin{array}{c}\text { Kelompok Tani } \\
\text { Milenial di Desa } \\
\text { Cepaka }\end{array}$ & 52 & 88 \\
\hline
\end{tabular}

Hasil tersebut menunjukkan bahwa pelatihan dan pendampingan tentang metode pembuatan simplisia daun pandan wangi mampu memberikan pemahaman kepada kelompok tani di Desa Cepaka, Kediri Tabanan sehingga dihasilkan produk simplisia.

\section{Pengemasan Produk dan Menentukan Merek Dagang}

Hasil dari kegiatan ini adalah merk dagang yang disepakati antara tim PKM dan mitra adalah "Melonila" Fragrant Pandanus Leaves. Produk dikemas dengan menggunakan plastik kedap udara netto 100 gram. Dengan adanya kemasan dan merk dagang ini diharapkan dapat meningkatkan harga jual produk. Adapun gambar produk simplisia dengan kemasan dan brand produk sebagai berikut:

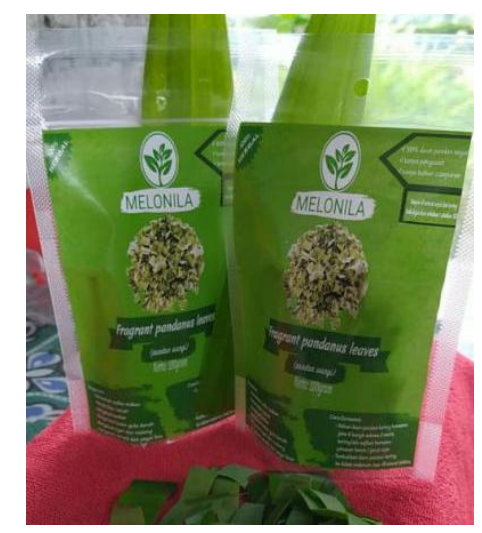

Gambar 2. Produk Simplisia Daun Pandan yang Dihasilkan

\section{KESIMPULAN}

Dari hasil kegiatan program kemitraan masyarakat di Desa Cepaka, Kediri Tabanan dapat disimpulkan beberapa hal sebagai berikut: 1)Semua anggota mitra yang mengikuti sosialisasi mendapatkan rerata nilai pemahaman 84 pada post-test; 2)Mitra memiliki keterampilan dalam membuat produk simplisia; 3)Produk simplisia yang dihasilkan memiliki merek dagang dan kemasan penjualan.

\section{DAFTAR PUSTAKA}

Dalimartha, S. 2002. Atlas Tumbuhan Obat Indonesia. Jilid 1. Jakarta: Trubus Agriwidya.

Notoatmodjo, S. 2012. Promosi kesehatan dan Perilaku Kesehatan. Jakarta: Rineka cipta.

Yadial, S. Z.T. 2009. Minuman Pandan Wangi (Pandanus amaryllifolius Roxb.) sebagai Minuman Sehat. Journal Sains and Technology, hal. 20-24 